\title{
Spatial Requirements for Cattle, Based on the Spatial Pattern in Grazing
}

Seiji Kondo and Yasushi AsAHIDA*

The College of Dairying, Ebetsu-shi 096-01

${ }^{*}$ Faculty of Agriculture, Hokkaido University, Sapporo-shi 060

(Received August 11, 1981)

For rearing cattle in groups, the estimation of the amount of space for one animal is a very important subject. Therefore, various sizes of space for group rearing have been recommended for each kind of herd. However, there still have been few basic studies concerning the size of space cattle require.

MCBRIDE ${ }^{1 \prime}$ has indicated that the amount of space an animal requires is the amount it occupies physically plus the amount it requires to control the intensity of social stimuli. For the latter amount, the relationship between the spatial pattern and the social behavior in cattle herds has not been obtained yet.

When grazing animals are in relatively large areas, they are more able to control by avoidance the intensity of the stimuli produced by neighbors, as compared to the restrictive spatial condition of feed lots. The area occupied by the grazing herd could give a helpful suggestion for the amount of space cattle require.

In the present study, the estimation of the space requirements for cattle was attempted on the basis of the area occupied by a resting herd.

\section{Materials and Methods}

Forty-one beef cattle, with live weight of approximately $240 \mathrm{~kg}$ in the spring of 1976, were observed during grazing on pastures at the Livestock Farm of Hokkaido University. The herd was rotationally kept about a week in three paddocks of 7.0, 4.2 and 2.3 ha. from May to October and observed from dawn to dusk. The behav. ioral patterns and the area occupied by the herd, measured within an imaginary line surrounding the entire herd, were recorded at hourly intervals. The ambient temperature was recorded by auto-recorders set on the neighboring paddock to the observation paddock.

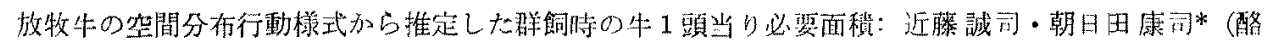
裖学園大学, 江别市 069-01, *北海道大学農学部, 札帽市 060) 


\section{Results and Discussion}

Fuller details of the diurnal and seasonal variations of the area occupied by the herd are reported elsewhere ${ }^{2}$. The data showed that the area occupied by the herd is associated with the behavioral pattern of the herd: the herd during grazing occupied the largest area at down and dusk, and the smallest was found at resting. These spatial patterns could be influenced by the grass yield and the ambient temperature.

Table 1 shows the areas occupied by a resting animal. These areas are expressed as the mean in a series of the observations in each paddock from May through October, along with the mean of the ambient temperature during each observation.

Table 1. Mean of the area occupied by an animal in the resting cattle herd $\left(\mathrm{m}^{2} / \mathrm{head}^{*}\right.$, mean ambient temperature $\left({ }^{\circ} \mathrm{C}\right)$, numbers of observation days and temperature range $\left({ }^{\circ} \mathrm{C}\right)$ in three paddocks from May through October

\begin{tabular}{|c|c|c|c|c|c|c|c|c|c|c|}
\hline \multirow{3}{*}{ month } & \multicolumn{9}{|c|}{ paddock } & \multirow{3}{*}{ temp. range } \\
\hline & \multicolumn{3}{|c|}{7.0 ha. } & \multicolumn{3}{|c|}{ 4. 2 ha. } & \multicolumn{3}{|c|}{2.3 ha. } & \\
\hline & area & temp. & $\mathrm{n}$ & area & temp. & $\mathrm{n}$ & area & temp. & $\mathrm{n}$ & \\
\hline May & 8.6 & 5.3 & 3 & 6.5 & 5.4 & 3 & 7.3 & 9.3 & 3 & $22.5--2.0$ \\
\hline May & 10.5 & 11.5 & 5 & 10.4 & 13. 1 & 5 & 10.0 & 12.1 & 5 & $20.5-1.0$ \\
\hline Jun. & 7.3 & 15.8 & 7 & 4.0 & 14.0 & 5 & 4.3 & 16.5 & 2 & $23.0-6.5$ \\
\hline Jul. & 5.9 & 17.6 & 6 & 1.8 & 21.7 & 3 & 2.4 & 18.0 & 3 & $34.0-8.5$ \\
\hline Aug. & 4.2 & 16.1 & 5 & 2.4 & 19.9 & 5 & 9.1 & 15.8 & 3 & $28.0-4.0$ \\
\hline Sep. & 5.7 & 16.4 & 6 & 3.8 & 14.2 & 4 & 17.5 & 12.4 & 3 & $22.0-4.0$ \\
\hline Oct. & 18.0 & 10.2 & 2 & 17.1 & 10.2 & 4 & 9.0 & 6.2 & 2 & $20.0--1.0$ \\
\hline mean & 8.6 & 13.3 & 4.9 & 6.6 & 14. 1 & 4. 1 & 8.5 & 13.0 & 3.0 & \\
\hline
\end{tabular}

* when $80 \%$ or more of all cattle in the herd were resting.

For the association of the area occupied by a resting animal and the mean ambient temperature, the following quadratic reggression equation was obtained.

$$
\mathrm{Y}=2.82+1.66 \mathrm{~T}-0.09 \mathrm{~T}^{2}
$$

where, $\mathrm{Y}$ : area occupied by a resting animal, $\mathrm{m}^{2} /$ animal

$\mathrm{T}$ : mean ambient temperature of each day, ${ }^{\circ} \mathrm{C}$

The effect of this reggression was highly significant $(P<0.01)$.

According to this equation, the maximum size of area occupied by a resting animal should occur at the mean ambient temperature of $9.2^{\circ} \mathrm{C}$. Below or above this mean temperature, the area occupied by a resting animal decreases. The minimum size of area would depend in part on a physical limitation of animal's own body-size.

The thermal comfort zone of European cattle is suggested approximately between 0 and $20^{\circ} \mathrm{C}^{3)}$. Thus, the areas occupied were estimated from the equation in the range of $5 \sim 15^{\circ} \mathrm{C}$, as the mean temperatures. Obtained values ranged from 7.47 to $10.47 \mathrm{~m}^{2}$ / animal. Since the paddock size did not influence the area occupied in this study, 


\section{Spatial Requirement for Cattle}

this range of area occupied could suggest the space an animal requires in the herd of 41 cattle including enough distance to control the social interaction without severe effect from temperature.

These estimated sizes of area occupied by resting cattle were a little larger than the recommended sizes of paved lots for heifers and dry cows in group rearing ${ }^{4}$. With beef cattle, a size of 9.3 or $12.0 \mathrm{~m}^{2} /$ animal was recommended for the space allowance per bullock including a manger area ${ }^{5}$. They were almost the same as the sizes of space estimated in this study.

Beef steers and heifers are best housed in groups with high stocking densities, $1.8 \sim 2.3 \mathrm{~m}^{2}$ of floor space being allowed each over $500 \mathrm{~kg}$ liveweight ${ }^{6)}$ with slatted floors. WiLsoN ${ }^{5)}$ suggested no relationship between performance and the space per animal within the range of 1.8 to $7.0 \mathrm{~m}^{2} /$ animal in intensive cereal beef units. Similarly, the study in dairy cows ${ }^{8}$ ) showed that reducing the space from 9.3 to $2.3 \mathrm{~m}^{2} /$ cow resulted in the decreasing activity and aggression in the herd, and no discernable effect on milk yield in the 4 week experiment.

These high stocking densities for cattle were corresponded to the area occupied by resting herds relative to hot or cold environments. However, such a considerably smaller space allowed for an animal may not be enough to control the social interaction for a long term, while it is adequate that the size of space for sun shade is recommended at from 1.8 to $2.3 \mathrm{~m}^{2} /$ animal $^{4}$.

In this study, the space allowance for cattle in groups was estimated from their spatial behavior in a herd of 41 similar-sized cattle. Further studies concerning the effect of group size and the structure of a herd on the space cattle require might be needed in relation to the whole environment.

\section{Acknowledgements}

The authors are grateful to The Livestock Farm of Hokkaido University for their support of this study and to Mr. J. M. ClaRKE for reviewing the manuscript.

\section{References}

1) McBride, G., in Adaptation of Domestic Animals. (HafEz, E. S. E., ed.) 361-366. Lea and Febiger. Philadelphia. 1978.

2) Kondo, S., T. Nona, Y. Asahida and Y. Hirose, Res. Bull. Livestock Farm, Fac. Agr. Hokkaido Univ., 9: 1-13. 1979.

3) Sainsbury, D. and P. Sainsbury, in Livestock Health and Housing. 2nd ed. 37-69. Bailliére Tindall. London. 1979.

4) Bates, D. W., T. J.Brevik, D. W. Johnson, R. K. Keith and J. H. Pedersen, in Dairy Housing and Equipment Hand Book, MWPS-7, 3-29. Midwest Plan Service, Iowa State University. Ames. 1976.

5) WIL son, H.C., in The Care and Management of Farm Animals. (Scotr, W. N., ed.) 29-52. Bailliére Tindall. London. 1978.

6) Arave, C. W., J. L. Albright and C. L. Sinclatr, J. Dairy Sci., 57: 1497-1501, 1974. 